\title{
VADOVAVIMO STILIŲ NUSTATYMAS KLAIPEDOS MIESTO PROGIMNAZIJOSE
}

\author{
Ligita Šimanskiené ${ }^{1}$, Arnoldas Petrulis $^{22}$ \\ Klaipedos universitetas (Lietuva)
}

\begin{abstract}
ANOTACIJA
Vadovavimo organizacijai klausimai buvo, yra ir bus aktualūs visais laikais, analizuojant vadovavimo stilius ir tai, kaip jie dera tarpusavyje. Straipsnyje analizuojami modernūs vadovavimo stiliai, pateikiant vadovavimo stilių vertinimo požymius. Atliktas tyrimas Klaipèdos miesto progimnazijose, siekiant nustatyti vadovų ir darbuotojų požiūrị ị taikomus vadovavimo stilius ir jų tinkamumą organizacijų veikloje. Nustatyta, kad darbuotojus paprastai tenkina vadovų pasirinktas vadovavimo stilius ar taikomi vadovavimo stilių deriniai.

PAGRINDINIAI ŽODŽIAI: vadovavimo stilius, organizacija, nustatymas, Klaipéda.
\end{abstract}

JEL KLASIFIKACIJA: M 12, M 10

DOI: http://dx.doi.org/10.15181/rfds.v13i2.829

Ivadas

Vadovavimas organizacijai, jos žmonėms yra veikla, kurią galima stebėti ir vertinti, atsižvelgiant ị vadovo pasirinktą vadovavimo stilių. Vadovavimo problemos ir asmeniniai vadovavimo stiliai egzistavo šimtus metų, visais istoriniais laikotarpiais. Šias problemas gvildeno, mokslinius tyrimus atliko ir išvadas aptare ịvairūs autoriai. Todèl vadybos mokslo literatūroje pateikiama ịvairių vadovavimo stilių, kurie suprantami ne tik kaip metodų, norimo elgesio rinkiniai, bet ir kaip galimybė keisti organizacijos darbinès veiklos būdus. M. Kets De Vries (Кетс де Врис, 2004: 26) teigimu, asmeninis vadovavimo stilius - tai visuma skirtingų vaidmenų, kuriuos prisiima žmonės, atsižvelgiant ir į charakterio bruožus, temperamentą bei igūdžius. Aiškinantis, kodèl vadovas pasirinko vieną ar kitą stilių, remiantis R. L. Draft, P. Lein (Дафт, Лейн 2007: 101104), reikia kreipti dèmesị ị du pagrindinius dalykus - sąlygas ir vadovavimo stilių lemiančius veiksnius bei paties vadovo galimybes ji kryptingai keisti, tobulinti. Vadovo vadovavimo stiliaus formavimuisi įtaką daro objektyvūs ir subjektyvūs veiksniai. Vadovo darbo sėkmé priklauso nuo jo gebejjimo teisingai ịvertinti savo pavaldinių brandumo lygị ir pasirinkti atitinkamą elgesio stilių. Taigi galima daryti išvadą, kad nèra vieno

$1 \quad$ Ligita Šimanskienè - profesorè, daktarè. Klaipėdos universiteto Socialinių mokslų fakulteto Vadybos katedra, Regioninės politikos ir planavimo centras

Moksliniai interesai: organizacinès kultūros tyrimai, İSA, konfliktų tyrimai organizacijose, komandinis darbas, kultūrų skirtumai, darnus regionų ir organizacijų vystymas

Adresas: Minijos g. 155, LT-93185 Klaipeda.

El. paštas: ligita.simanskiene@gmail.com

Tel.: +37046398 596; +37046398597

2 Arnoldas Petrulis - verslo vadybos magistrantas. Klaipėdos universiteto Socialinių mokslų fakulteto Vadybos katedra

Moksliniai interesai: organizacijų valdymas, vadovavimo stiliai

Adresas: Minijos g. 155, LT-93185 Klaipeda.

El. paštas: arnius1971@gmail.com

Tel.: +37067344429 
geriausio vadovavimo stiliaus, sėkmingas vadovavimas turi būti individualizuotas, t. y. elgesys pasirinktas, atsižvelgiant ị konkretaus pavaldinio ar jų grupès pasirengimo darbui lygị. Konkrečiu laikotarpiu, keičiantis šalies išsivystymo lygiui, kuriasi naujos organizacijos, kinta vadovavimo stiliai, todèl vadovavimo stiliaus pasirinkimo problema tampa vis svarbesnè. Vienas svarbiausių vadovavimo elementų (Sadeghi, Pihie, 2012: 187), turintis įtakos vadovavimo veiksmingumui, yra vadovavimo stilius. Vadovai savo vadovavimo stiliu ištobulina per tam tikrą laikotarpi, igydami patirties, nuolat gilindami žinias ir tobulindami jų panaudojimą.

Mokslinè problema. Nors publikuota nemažai mokslinių straipsnių ar knygų apie vadovavimo stilius, juose vis dèlto dažniau percituojami užsienio mokslininkų darbai. Deja, Lietuvos mokslininkai naujais vadovavimus stiliais (galima būtų juos taip įvardyti, nes transformaciniai ir transakciniai vadovavimo stiliai pradèti analizuoti praèjusio šimtmečio pabaigoje) vis dar nepakankamai domisi, o jų derinimui apskritai neskiria dėmesio, konstatuodami a priori, kad geriau derinti skirtingus stilius. Taigi „rimto“ požiūrio ị šią vis dar aktualią vadovavimo stilių problemą pasigendama. Todèl formuluojame tokią mokslinę problemą: nepakankamas vadovavimo stilių suvokimas, identifikavimas ir derinių nustatymas organizacijose.

Šio straipsnio tikslas: išanalizavus teorinius vadovavimo stilius, nustatyti, kokie vadovavimo stiliai taikomi Klaipedos miesto progimnazijose.

Tyrimo objektas - vadovavimo stiliai Klaipédos miesto progimnazijose.

Tyrimo metodai: siekiant pagrịsti vadovų taikomų vadovavimo stilių tinkamumo būtinybę, remtasi mokslinès literatūros įžvalgomis, atlikta analizè, sintezè, palyginimas. Atliktas individualus darbuotojų anketavimas, tiriant vadovus taikytas interviu metodas. Sisteminant ir grafiškai vaizduojant duomenis pasitelkta SPSS 18 (angl. Statistical Package for the Social Sciences) programinè ir Microsoft Office Excel 2010 programa.

\section{Vadovavimo stilių apžvalga}

Nors, kaip minèta, vadovavimo stiliai visada domino vadybos mokslo mokslininkus ir praktikus, tačiau XX amžiaus 7-9 dešimtmečiuose prasidèjo vadovavimo stilių tyrimo atgimimas. Modernius (šiuolaikiškus) arba pažinimo vadovavimo stilius - charizmatinį, transakcinį, transformacinį, ugdantiji - nagrinejjo mokslininkai: D. Goleman, R. Boyatzis, A. McKee (2007); L. Dubkēvičs (2011); S. Amirul, H. Daud (2012). Glaustai aptarsime kiekvieną jų.

Charizmatinis (patrauklus) vadovavimo stilius. R. N. Lussier ir C. F. Achua (2001: 375) minimas vokiečiu sociologas $M$. Weber vartojo charizmos terminą, siekdamas paaiškinti įtakos tipą, kuris nuo tradiciniu autoriteto tipų skiriasi tuo, kad vadovas yra apdovanotas aukštesnèmis galiomis arba antgamtinėmis savybėmis. A. Stankevičienès ir L. Lobanovos (2006: 146) nuomone, charizmatiškas vadovas yra žavus, geba sukelti intensyvius pavaldinių jausmus - meilę ar neapykantą, darbuotojai siekia su tokiu vadovu susitapatinti. Charizmatiško vadovo ir jo darbuotojų santykiai paprastai būna emocionalūs. R. L. Daft ir P. Lein (Дафт, Лейн, 2007: 119) teigia, kad charizmatinis vadovas geba įkvėpti ir taip paskatinti darbuotojus, kad jų atliekami veiksmai viršytų ịprastines jų galimybes, kartu jie nepaiso jokių kliūčių ar asmeninių aukų. S. P. Robbins (2010: 77-78) tvirtina, kad charizmatinio elgesio galima išmokti ir naudotis charizmatiniam vadovui skirtomis privilegijomis. Jie skiria šias savybes: pasitikèjimas savimi, tvirta vizija, siūlanti geresnę ateitį, gebejjimas tą viziją įvardyti, tvirtas tikẻjimas ja ir pasiryžimas vykdyti radikalius pokyčius. S. Khan, M. A. Anjum (2013: 56) pastebi, kad daugelis mokslininkų charizmatišką vadovavimą traktuoja kaip didelę galią, įtaką jų sekëjams. Vis dèlto yra mokslininkų, kurie pabrèžia nepageidaujamus charizmatiško vadovavimo požymius (lyginami Mahatma Gandhi ir Hitleris). Todėl šiuolaikinèje visuomenėje, apibūdindami charizmatinị vadovavimo stilių, daugelis autorių pabréžia, kad vadovas savo gebejjimus turi kreipti darbuotojų ir visuomenès labui. Nes išskirtinių gebejjimų pritraukti ir paveikti turintis piktavališkas vadovas gali tai panaudoti savo asmeniniams, galbūt piktavališkiems poreikiams, kurie būtų žalingi ne tik darbuotojams, bet ir visuomenei.

Transakcinio (pagrịsto mainais) vadovavimo stiliaus, kuris pradètas taikyti apie 1978 metus, pradininkas yra J. M. Burns (Sabir, Sohail, Khan, 2011: 146). Transakciniai vadovai nustato, ką darbuotojai 
turi nuveikti, kad pasiektų savo individualius ir visos organizacijos tikslus, klasifikuoja šiuos reikalavimus ir padeda darbuotojams igyti pasitikèjimo, kad labai pasistengę, šie galètų išsikeltus tikslus pasiekti. W. Havenga, V. Mehana, J. C. Visagie (2011: 12274) tokị vadovavimo stilių vadina atpildu pagrịsta valdžia - tai prievartinès valdžios priešingybė. Anot R. L. Daft ir P. Lein (Дафт, Лейн, 2007: 123), transakcinis vadovas labiau linkęs laikytis nusistovejjusių bendruomeninių taisyklių, todėl siekia stabilumo, o ne pokyčių. Remdamiesi nagrinèta moksline literatūra, skirsime keturias transakcinio vadovo savybes: tikslų ịvardijimas; veiklos stebejjimas; grịžtamojo ryšio suteikimas; karjeros planavimas.

Transformacinis (pokyčių) vadovavimo stilius. A. Stankevičienės, L. Lobanovos (2006: 146) teigimu, transformacinis vadovavimas pripažįsta daugelio darbe pasitaikančių situacijų neracionalumą. Toks vadovavimas apima bent vieną iš šių reiškinių: skatinimą (saviskatą), moralę ar ịsipareigojimus tiesioginiams darbuotojams. Vadovas, taikantis transformacinị vadovavimo stilių, domisi savo pavaldiniais, jų atliekamu darbu, profesiniu tobulèjimu, skatina darbuotojus mąstyti, apsvarstant sprendimus pasitelkti vaizduotę, ịkvepia juos imtis naujų užduočių, reikšti idejjas (Gustainienè, Pranckevičienė, Briedaitytė, 2012: 313). B. J. Monahan $(2012:$ 60-61, 107) disertacijoje apie vadovą aprašo vieną iš tyrimo dalyvių, kuris savo pagrindinị vadovavimo stilių ịvardija kaip transformacinị. Ištyrinèjus mokslinę literatūrą paaiškejjo, kad transformacinis vadovavimas yra tinkamas vadovavimo stilius, kuris turi būti taikomas organizacijose per krizę (Harwati, 2013: 178). Remdamiesi nagrinèta moksline literatūra, skiriame keturis transformacinio vadovo gebejjimus: vizijos sukūrimas ir ịkvėpimas (idealizuota įtaka); aplinkos, kuri skatina, sukūrimas; veikimo būdų numatymas; gebėjimas kūrybiškai bendrauti su žmonèmis.

Ugdomasis (instruktuojantis) vadovavimo stilius. Anglų kalboje Coach reiškia vadovas, taikantis ugdomajji vadovavimą, deja, lietuvių kalboje tinkamo šio žodžio atitikmens nèra, todèl dažniausiai vartojamos angliškos sąvokos variantas koučingas. O. J. Savruk (Саврук, 2009: 76, 81) siūlo taikyti ugdomaji vadovavimo stilių atsižvelgiant ị darbuotojų asmeninę raidą. Šis vadovavimo stilius nukreiptas ị darbuotojo profesinị tobulinimą, kai vadovas pataria ir padeda darbuotojui atrasti sprendimus vykdant paskirtas užduotis. M. A. Lutohinos (Лутохина, 2008: 62), E. N. Dmitrijevos, N. A. Trenkajevos (Дмитриева, Тренькаева, 2008: 145) nuomone, vadovas sutelkia dèmesị ị darbuotojų ugdymą, padeda skleistis jų kūrybiškumui, skatina nestandartinị požiūrị ị darbo problemas, jų sprendimą. S. Dhomne, S. P. Hall (2012: 68) mano, kad tinkamas bendravimas ir žmonių mokymas yra du šio vadovavimo stiliaus sėkmės raktai. Ugdomaji (koučingo) vadovavimo stilių apibūdintume kaip vadovavimą, kai organizacijos darbuotojai pripažistami kaip jos turtas ir sèkmès garantija. Tai vadovavimo stilius, nukreiptas ị organizacijos žmonių išteklius visuose lygiuose, kuriantis išskirtinę organizacinę kultūrą ir pripažịstantis komandinį darbą, pasidalijant vadovavimo funkcijas, bet išlaikant pavaldumo principą. Remdamiesi analizuota moksline vadybos literatūra skirtume tokius penkis vadovo gebejimus: aiškiau suvokti iškilusią problemą; perprasti ir išsprendžiant pakeisti sudètingas ar dviprasmiškas situacijas; suformuoti organizacinę kultūrą, nustatyti jos pobūdị; pasirinkti tinkamus sudètingų užduočių atlikimo būdus; rodyti veiksmingą pavyzdị, nuolat įvertinti vadovavimo rezultatus.

\section{Vadovavimo stiliaus vertinimo požymiai}

Siekdami ištirti vadovavimo stilius konkrečiose organizacijose, nusprendėme išanalizuoti požymius, pagal kuriuos vertinami vadovavimo stiliai.

Labai svarbu, kaip vadovas elgiasi, bendrauja su darbuotojais, suteikia jiems ịgaliojimus, rūpinasi kolektyvo tarpusavio santykiais. Dauguma bruožų, poelgių ir elgesio modelių pasireiškia kaip būdingi ir lyderiui, ir autoritariniam vadovui, tuo tarpu situacijos, kuriomis šios asmeninès savybès ar elgsena pasireiškia, būna skirtingos. Būna situacijų, kai viskas iš esmés priklauso nuo susiklosčiusios padèties, tačiau mokslininkai tai aiškina kaip skirtingų vadovavimo stilių taikymą skirtingomis aplinkybėmis (Stankuvienė, 2013: 66). Laikui bėgant, mokslininkai apibrèžè, kas yra idealizuota ịtaka darbuotojams, kuri dar vadinama charizmatiniu vadovavimu (Aydogdu, Asikgil, 2011: 66). A. Fukushige ir D. P. Spicer (2007: 524) atliko tyrimą (pagal vadovavimo stilių vertinimo požymius) ir nustate prieštaravimą B. M. Basso ir B. J. Avolio teiginiui, kad 
nepaisant esamos kultūros pirmenybė teikiama (žmonès renkasi) visiems transformaciniams, o ne transakciniams vadovavimo stiliams.

Remiantis surinktais duomenimis (žr. 1 lentelę) ir analizuojant mokslinę literatūrą, tolesniam vadovavimo stiliaus vertinimo tyrimui pasirinksime požymius, kurie minèti visų autorių: užduočių pateikimas; požiūris ị iniciatyvą; požiūris ị darbuotojus; santykių su darbuotojais pobūdis; požiūris ị vertybes ir vizijos perteikimas.

Svarbu nustatyti ir vadovavimo stilių suderinamumą.

1 lentele. Vadovavimo stiliaus vertinimo požymiai

\begin{tabular}{|c|c|c|c|c|c|c|c|c|c|}
\hline$x$ & 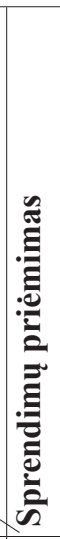 & 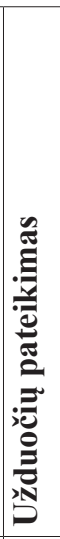 & 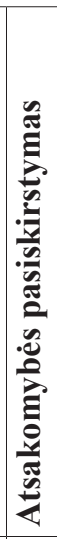 & 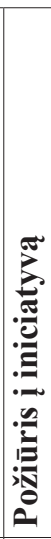 & 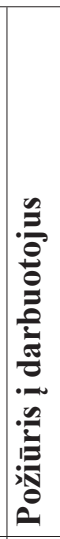 & 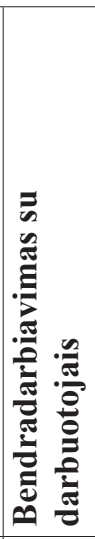 & 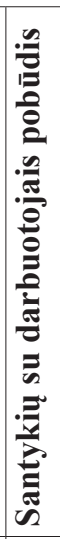 & 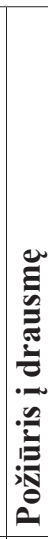 & 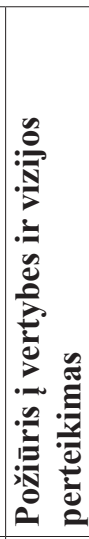 \\
\hline G. Genevičiūtè-Janonienè, A. Endriulaitienè (2010) & - & + & + & + & + & - & + & + & + \\
\hline A. Stelmokienè, A. Endriulaitienè (2012) & + & + & + & + & + & + & + & - & + \\
\hline A. Stankuvienè (2013) & + & + & + & + & + & + & + & + & + \\
\hline L. N. Harwati (2013) & + & + & - & + & + & + & + & - & + \\
\hline L. C. Batista-Taran ir kt. (2013) & + & + & + & + & + & + & + & + & + \\
\hline S. Aydogdu, B. Asikgil (2011) & - & + & + & + & + & - & + & - & + \\
\hline A. Fukushige, D. P. Spicer (2007) & + & + & + & + & + & + & + & + & + \\
\hline A. Sadeghi, Z. A. L. Pihie (2012) & - & + & - & + & + & - & + & - & + \\
\hline
\end{tabular}

Pastaba: sudaryta darbo autorių

\section{Vadovavimo stilių suderinamumas}

B. M. Bass nuomone, kiekvienas vadovas tam tikru mastu pritaiko abiem stiliams (transakciniam ir transformaciniam) būdingus gebejjimus (Ibrahim, Al-Taneiji, 2013: 43). Jo teigimu, transformacinis ir transakcinis vadovavimas gali vienas kitą papildyti: vienu atveju skatins darbuotojus imtis iniciatyvos (transformacinis vadovavimas), o tiems, kurie to nesugeba, bus pasiūlyti konkretūs būdai, kaip siekti tikslų (transakcinis vadovavimas). R. L. Daft ir P. Lein nuomone, vadovavimo stilių suderinamumas priklauso nuo to, kaip vadovas siekia paveikti darbuotoją, kokius renkasi situacinius valdymo metodus ir koks yra pačiu darbuotojų žinių ir gebejjimų lygis (Дафт, Лейн, 2007: 54-55). I. К. Adizes (Адизес, 2007: 165, 192) siūlo per pirmą susitikimą su darbuotoju atkreipti dèmesị i i ivairias jo bendravimo smulkmenas ir iš pradžiu taikytis prie jo bendravimo stiliaus, kol vadovas pajus, kad darbuotojas pradeda jaukiai jaustis (nejaučia baimès bendraudamas su vadovu) ir supranta (paprasti, aiškūs žodžiai), ką šis jam sako. D. Goleman, R. Boyatzis, A. McKee teigè, kad „didelès reikšmès turi įvairių vadovavimo stilių kaitaliojimas (...). Skiriant vadovą, reikètų rasti tokị asmenị, kuris būtų ịvaldęs (...) daugiau vadovavimo stilių ir sugebètų lanksčiai juos taikyti““ (2007: 88). P. Zakarevičius pastebi, kad ,vadovaujama integruojant atskirus stilių tipus: vienose situacijose akcentuojant vieno stiliaus, kitose - kito stiliaus vadovavimą“" (2004: 3).

Renkantis darnų vadovavimo stilių būtina, kad derinamos sampratos viena kitą papildytų, o visos kartu sudarytų darnią visumą. Taigi vadovavimo stilių derinimas, šio straipsnio autorių nuomone, - tai ne tik kla- 
sikinių ir modernių vadovavimo stilių suderinamumas, bet gali būti ir vieno vadovavimo stiliaus elementų (pobūdžių) tiesioginis perkèlimas ị kitą vadovavimo stilių, derinant asmenines vertybes ir ịsitikinimus su organizacijos vertybėmis, kai siekiama norimo rezultato.

\section{Tyrimo metodika}

Šiuo metu Klaipėdos mieste yra 42 mokymo įstaigos, tarp jų 10 progimnazijų ir 13 pagrindinių mokyklų. Tyrimui atlikti pasirinktos 8-ios tą pačią veiklą vykdančios organizacijos, t. y. Klaipėdos miesto progimnazijos. Šių organizacijų vadovai geranoriškai sutiko, kad jų darbuotojai ir jie patys dalyvautų tyrime, kurio tikslas - nustatyti Klaipedos miesto progimnazijų vadovų vadovavimo stilius. Šiuo atveju esama tam tikro tyrimo apribojimo, nes vadovai sutiko dalyvauti tyrime tik tuo atveju, jei bus pateikti apibendrinantys visu progimnazijų vadovų vadovavimo stilių vertinimai, o ne kiekvieno atskirai. Vadovai nenori būti asmeniškai identifikuoti, ypač nežinodami, kokie bus gauti tyrimų rezultatai. Tyrimas atliktas 2014 metų vasario - balandžio mènesiais.

Pasirinktas tyrimo instrumentas: anketa sudaryta iš uždarųų ir atvirųų klausimų. Prie atvirujų klausimų palikta galimybè respondentams patiems įrašyti atsakymą. I uždarojo tipo klausimus atsakymai pateikiami iš anksto, respondentui telieka pasirinkti vieną iš jų, geriausiai atitinkantị jo požiūrị. İ atvirojo tipo klausimus respondentui būtina atsakyti pačiam, tai priskiriama prie teigiamų savybių. Paprastai tokius anketos klausimus užpildo mažas procentas apklaustujų̨. Sudarant klausimus, pasirinkimų sąraše pateikiama tiek pat teigiamų (patvirtinančių nuomonę) ir neigiamų (prieštaraujančių) atsakymų. Anketos klausimų skalès: klasikinė ranginè, arba intervalo, skalè (objektyvių duomenų apie respondentą nustatymas) - 6 klausimai; ranginė skalè - 1-as kalusimas, ranginè Likerto skalè - 4-as ir 5-as klausimai, nominali skalè - 2-as ir 3-ias klausimai. Tyrimo büdas: trumpalaikis tyrimas, K. Kardelio teigimu, dar vadinamas „skerspjūvio“, arba momentiniu, vienkartiniu, tyrimu (1997: 79); V. Pruskaus teigimu - vienkartiniu tyrimu (2004: 175). Respondentu atrankos metodai: paprasta atsitiktinè-tikimybinė atranka, kurios metu kiekvienas imties dalyvis turi galimybę būti apklaustas (Rudzkienè, 2005: 18). Imčiu atrinkimas ir tiriamoji visuma: generalinė imtis - abiejų lyčių, skirtingo amžiaus Lietuvos gyventojai, Klaipėdos miesto progimnazijų (Gabijos, M. Mažvydo, Smeltès, L. Stulpino, Tauralaukio, Verdenès, Versmės ir Sendvario) darbuotojai, specialistai, kurie tiesiogiai užtikrina mokinių ugdymą ir neformalų švietimą. Tyrimo visuma $(N)$ - sluoksninè imtis, kai numatyta apklausti organizacijų vadovus ir asmenis, kurie tiesiogiai dalyvauja ugdymo procese (Rudzkienè, 2005: 18). Imties dydis apskaičiuojamas esant $\pm 5 \%$ pasikliautinajam intervalui ir $95 \%$ pasikliovimo lygiui. K. Kardelio (1997: 161) teigimu, moksliniuose darbuose paprastai pasikliaujama $95 \%$ patikimumu.

Tiriamose organizacijose dirba 8 aukščiausiojo lygio vadovai ir 20 aukštesniojo lygio vadovų. Apklausti 7 direktoriai ir 15 direktoriaus pavaduotojų. Tiriamose organizacijose dirba 457 (iskaitant ir mokyklos direktoriu pavaduotojus) ugdymo specialistai, kurie gali pateikti savo nuomonę, vertindami tiesioginio vadovo vadovavimo stilių. Skaičiuojant pagal Paniotto formulę, kai leistinas netikslumas $\Delta=0,05$ (5\%), turime apklausti 213 ugdymo specialistų. Tiek jų ir apklausėme.

Klausimyno patikimumui nustatyti skaičiuotas Cronbach alpha koeficientas. Vadovų anketų Cronbach alpha koeficientas sudaro 0,69, taigi patikimumas pakankamas. Darbuotojų anketu Cronbach alpha koeficientas sudaro 0,801 , taigi patikimumas aukštas. Tyrimo rezultatai yra reprezentatyvūs tik nagrinejjamų organizacijų atžvilgiu, jokie apibendrinimai visų mieste veikiančių ar panašia veika užsiimančiu organizacijų atžvilgiu negali būti daromi. Tai yra pagrindinis darbo ribotumas. Pažymėtina, kad direktorių pavaduotojų, kurie dalyvauja apklausoje kaip darbuotojai, vertinantys tiesioginio vadovo vadovavimo stilių, yra 10 (anketų), apklausiamų vertinat savo vadovavimo stilių - 15 (anketų). Prie pareigybių kita buvo taip nurodyta: pagalbos mokiniui specialistas - 2 (anketos), psichologas - 2 (anketos), specialioji pedagogè - 1 (anketa), švietimo pagalbos specialistas - 1 (anketa). 


\section{Vadovavimo stilių nustatymo rezultatų analizé}

Apklausoje dalyvavusių organizacijų darbuotojams buvo pateiktas klausimas, ar galètumète teigti, kad Jūsų organizacijos vadovo pasirinktas vadovavimo stilius jus tenkina? Prašyta pasirinkti vieną iš galimų atsakymų variantų: taip, visiškai tenkina; daugiau tenkina, nei netenkina; daugiau netenkina, nei tenkina; ne, visiškai netenkina. Atitinkamai organizacijų vadovams pateiktas klausimas, ar galètumète teigti, kad Jūsų pasirinktas vadovavimo stilius tenkina Jūsų organizacijos darbuotojus?

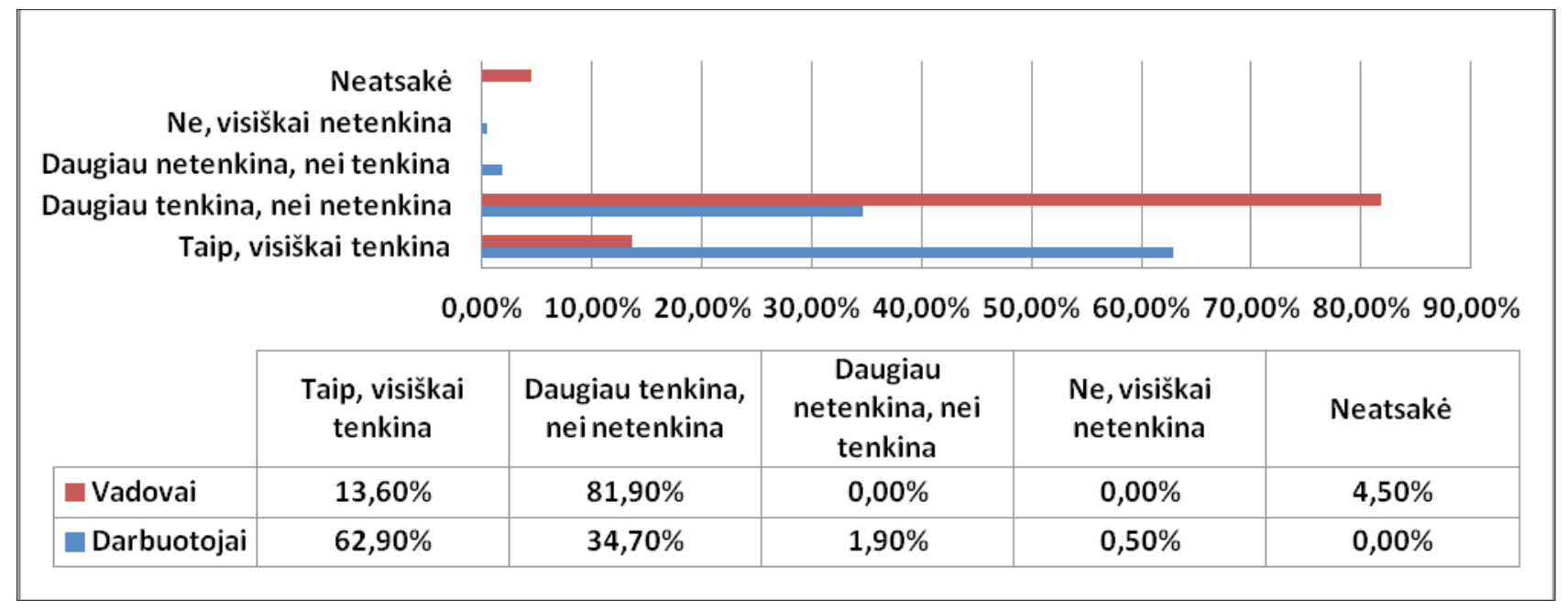

1 pav. Respondentų pasitenkinimas vadovavimo stiliumi organizacijoje (procentais)

Pastaba: sudaryta darbo autorių, remiantis anketų duomenimis.

Didžioji dauguma tiriamų progimnazijų vadovų, t. y. 18 iš 22 , pasirinko atsakymą daugiau tenkina, nei netenkina. Darbuotojai vadovavimo stilių įvertino geriau, nei save įsivertino patys vadovai. Taigi susidaro įspūdis, kad vadovai nèra įsitikinę, kad jų pasirinktas vadovavimo stilius yra visiškai tinkamas.

Siekdami ịvertinti organizacijų vadovavimo stilius, respondentams (organizacijų darbuotojams) pateikème penkias vadovavimo charakteristikas: užduočių pateikimo būdas; požiūris ị darbuotojų iniciatyvos pasireiškimą; požiūris ị darbuotojus; santykių su darbuotojais pobūdis; požiūris ị vertybes ir vizijos perteikimas. Paprašème kiekvieną iš jų ịvertinti nuo 1 iki 5 , kur 1 - visiškai nesutinku, o 5 - visiškai sutinku, siekdami nustatyti, kuris iš jų labiausiai tenkina ir yra priimtiniausias darbuotojams. Organizacijų vadovų prašyta ìvertinti tokias pačias vadovavimo stilių charakteristikas, kokios buvo pateiktos organizacijų darbuotojams, siekiant įvertinti pačių vadovų nuomonę, kuri iš charakteristikų jų darbuotojams būtų priimtiniausia. Naudojantis aprašomosios statistikos (angl. Descriptive Statistics) programa išvesti vidurkiai, procentinè išraiška pateikta 2 paveiksle.

Ivertinus atsakymus nustatytos šios vadovavimo stiliaus charakteristikos: užduočiu pateikimo būdas ir požiūris ị darbuotojus panašiai vertinami tiek tyrime dalyvavusių progimnazijų darbuotojų, tiek progimnazijų vadovų. Santykiai su darbuotojais darbuotojų ịvertinti geriau nei pačių organizacijų vadovų. O požiūris ị darbuotojų iniciatyvos pasireiškimą ir požiūris $\dot{i}$ vertybes ir vizijos perteikimas, remiantis vidurkiu, yra 1-oje ir 2-oje vietoje pagal priimtinumą. Vadovai mano, kad darbuotojams priimtinesnis požiūris $i$ darbuotoju iniciatyvos pasireiškima, nei požiūris i vertybes ir vizijos perteikima. Darbuotojų atsakymai atskleidè, kad, remiantis progimnazijų darbuotojų anketų suvestinių vidurkiu, aukščiau ịvertintas vadovavimo stiliaus bruožas požiüris i vertybes ir vizijos perteikimas. 
Apibendrinantys ištirtų progimnazijų darbuotojų ir vadovų nuomonių dẻl vadovavimo stilių organizacijose pagal išskirtus vadovavimo požymius duomenys pateikti 2 lentelëje.

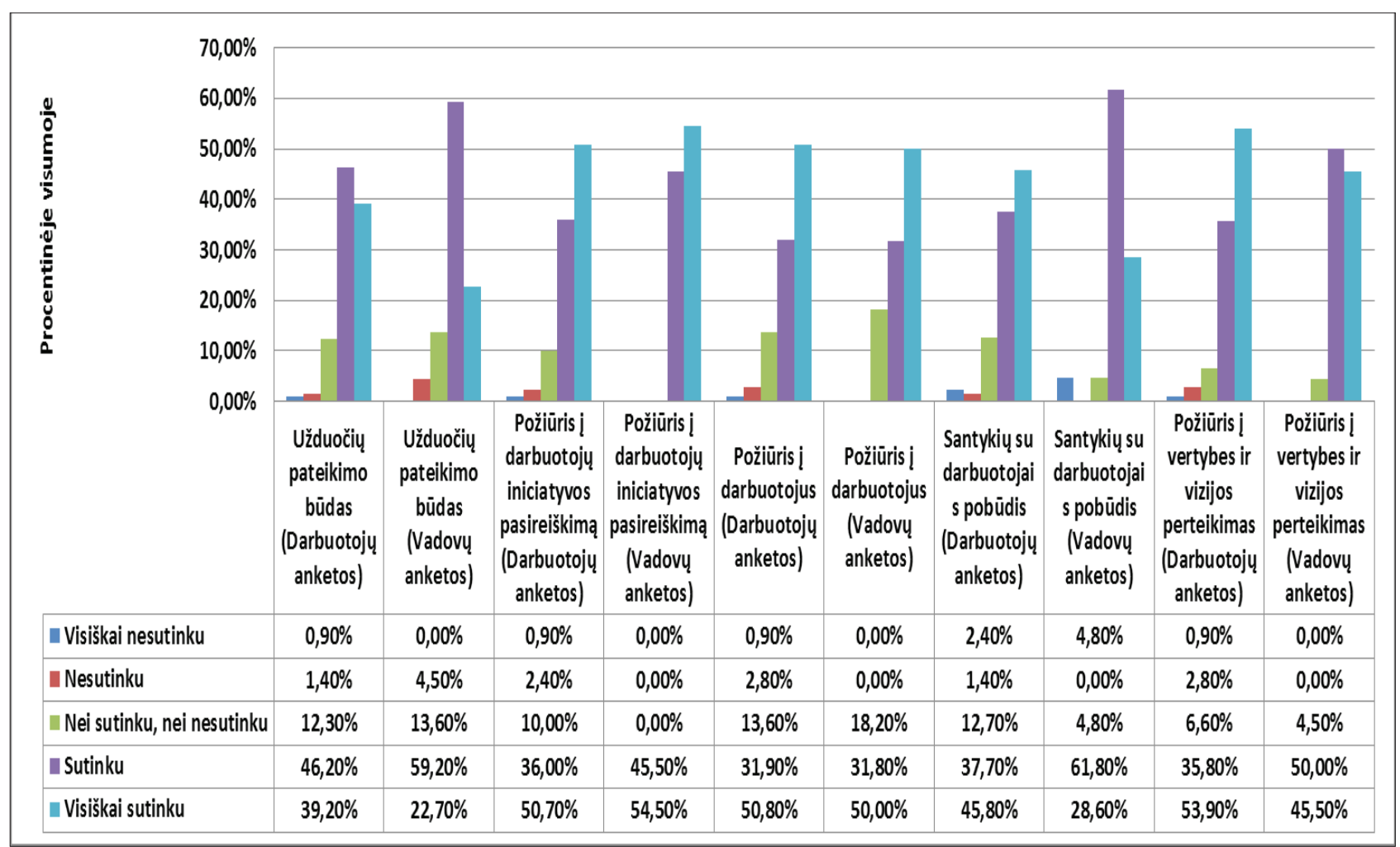

2 pav. Respondentų pasitenkinimas vadovavimo stiliumi organizacijoje (procentais) Pastaba: sudaryta darbo autorių, remiantis anketų duomenimis

2 lentele. Vadovavimo stilių deriniai

\begin{tabular}{|c|c|c|}
\hline Požymis & Darbuotojų vertinimai & Vadovų vertinimai \\
\hline $\begin{array}{l}\text { Požiūris ị darbuotojų } \\
\text { iniciatyvos pasireiškimą }\end{array}$ & $\begin{array}{l}\text { Transformacinio ir ugdomojo vadovavimo } \\
\text { derinys, kartais - charizmatinio ar } \\
\text { transakcinio derinys }\end{array}$ & $\begin{array}{l}\text { Transformacinio ir ugdomojostilių derinys, } \\
\text { nevengiant charizmatinio ar transakcinio } \\
\text { stilių }\end{array}$ \\
\hline Užduočių pateikimo būdas & $\begin{array}{l}\text { Transformacinio, charizmatinio, ugdomojo } \\
\text { ir transakcinio stilių derinys }\end{array}$ & $\begin{array}{l}\text { Transformacinio, ugdomojo ir charizmatinio } \\
\text { stilių derinys }\end{array}$ \\
\hline Požiūris ị darbuotojus & $\begin{array}{l}\text { Ugdomojo ir transformacinio stilių derinys, } \\
\text { kartais - charizmatinio ar transakcinio }\end{array}$ & $\begin{array}{l}\text { Ugdomojo ir transformacinio stilių derinys, } \\
\text { nevengiant transakcinio stiliaus }\end{array}$ \\
\hline $\begin{array}{l}\text { Požiūris ị vertybes ir vizijos } \\
\text { perdavimas }\end{array}$ & $\begin{array}{l}\text { Ugdomojo ir transformacinio stilių derinys, } \\
\text { kartais - charizmatinis }\end{array}$ & $\begin{array}{l}\text { Ugdomojo ir transformacinio stiliu derinys, } \\
\text { kartais - charizmatinis }\end{array}$ \\
\hline $\begin{array}{l}\text { Santykių su darbuotojais } \\
\text { pobūdis }\end{array}$ & $\begin{array}{l}\text { Transformacinio ir ugdomojo stilių derinys, } \\
\text { kartais - charizmatinio ar transakcinio } \\
\text { derinys }\end{array}$ & $\begin{array}{l}\text { Transformacinio ir ugdomojo stilių derinys, } \\
\text { nevengiant transakcinio stiliaus }\end{array}$ \\
\hline
\end{tabular}

Pastaba: sudaryta darbo autorių, remiantis tyrimo rezultatais.

Šis vadovavimo stilių vertinimo tyrimas patvirtina vadybos autorių nuomonę apie vadovavimo stilių suderinamumą (žr. 3 paveikslą). 


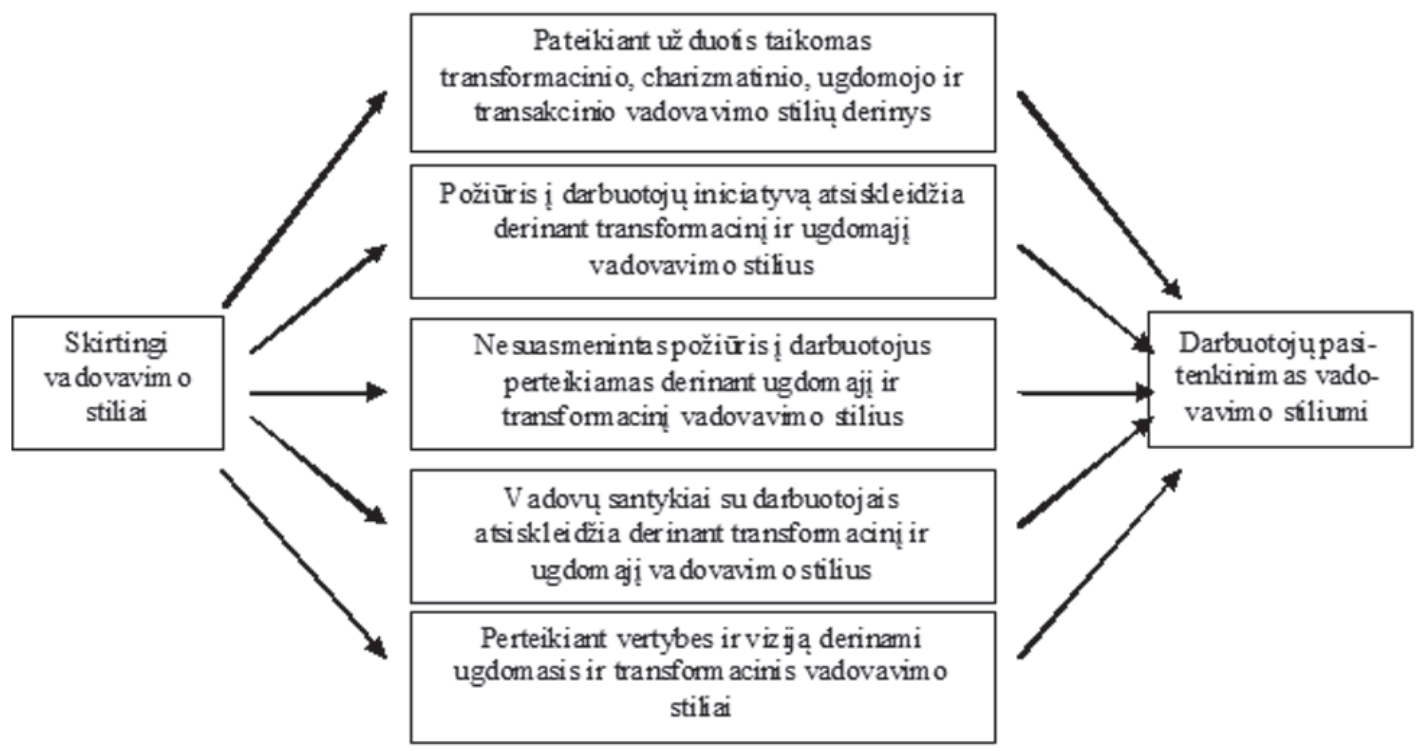

3 pav. Darbuotojus tenkinantys vadovavimo stilių deriniai

Pastaba: sudaryta darbo autorių, remiantis tyrimo rezultatais

Remiantis respondentų atsakymų duomenimis, galima daryti tokias išvadas: vadovų nuomone, jų vadovavimo stiliaus pagrindą sudaro transformacinio ir ugdomojo vadovavimo stilių derinys, nevengiant priderinti charizmatinio ar transakcinio vadovavimo stilių; darbuotojų nuomone, tiesioginiai vadovai savo darbe derina transformacinị ir ugdomaji vadovavimo stilius, kartu taikydami ir charizmatinị ar transakcinị vadovavimo stilius.

Apibendrinant tyrimo rezultatus galima teigti, kad tyrime dalyvavusių progimnazijų vadovų ir darbuotojų anketų suvestinių duomenys yra panašūs. Jie atskleidžia, kad progimnazijų vadovų vadovavimo stilių pagrindą sudaro transformacinio ir ugdomojo vadovavimo stilių derinys. Būtent šis derinys, prie jo priderinus charizmatinị vadovavimo stilių, labiausiai tenkina organizacijų darbuotojus.

Išvados

Išanalizavus vadovavimo stilius nustatyta, kad apibūdinti vadovavimo stilius moksliniu pagrindu, juos sisteminti ir sugrupuoti iš esmès pradèta XX a. pradžioje, nors bandymų būta ir anksčiau. Vadovavimo stiliai priskiriami prie modernių arba pažinimo (transformatyvių) stilių: charizmatinis (patrauklus), transakcinis (dalykinis arba santykių, sąveikos), transformacinis (pokyčių), ugdomasis (koučingo, instruktavimo, treniravimo). Taigi daroma išvada: išplètotų teorijų, apibrěžiančių vadovavimo stilius, yra nemažai, bet ši mokslinè veikla plètojama toliau, darbai šiandien dar nebaigti, nes atsiranda vis naujų vadovavimo stilių, jie įvairiai apibūdinami ir grupuojami, skirstomis pagal išskiriamus požymius.

Atskleidžiant modernių vadovavimo stilių suderinamumą, galima paminèti šiuolaikines vadovavimo stilių teorijas, kurios teigia, kad vadovas turi sugebèti taikyti visus konkrečiai situacijai organizacijoje tinkamus stilius, metodus ir poveikio priemones, ypač transformacinį vadovavimo stilių, papildant jị charizma (jei vadovas sugeba). Sèkmingas vadovavimas - tai gebèjimas susieti geriausius kiekvieno stiliaus bruožus ị vientisą vadovavimo visumą, keisti stilius, išnaudoti kiekvieno privalumus, atsižvelgiant ị susiklosčiusią padètį.

Atliktas tyrimas tik patvirtino teorineje šio darbo dalyje mokslininkų išsakytas mintis, kad nèra vieno visiems atvejams labiausiai tinkamo vadovavimo stiliaus. Ištyrus darbuotojų nuomones apie vadovų stilius nustatyta, kad organizacijų vadovai, atlikdami savo tiesiogines pareigas, derina kelis vadovavimo stilius. Tyrimas atskleide, kad organizacijų vadovų pasirinktas vadovavimo stilių derinys visiškai tenkina arba daugiau tenkina, nei netenkina didžiąją dalị tirtų organizacijų darbuotojų. Gauti vertinimų rezultatai atskleidè, 
kad darbuotojai geriau įvertino vadovų taikomą vadovavimo stilių, nei tai padare patys vadovai. Atliktame tyrime darbuotojų nuomonės labai artimos vadovų nuomonėms dẻl vadovavimo stiliaus ar skirtingų stilių derinio pasirinkimo.

\section{Literatūra}

Amirul, Sh. R., Daud, H. N. (2012). A study on the relationship between leadership styles and leadership effectiveness in Malaysian GLCs. European Journal of Business and Management, Vol. 4, No. 8, p. 193-201. Publisher: International Institute for Science, Technology and Education.

Aydogdu, S., Asikgil, B. (2011). The Effect of Transformational Leadership Behavior on Organizational Culture: An Application in Pharmaceutical Industry. International Review of Management and Marketing, Vol. 1, No. 4, p. 6573. Mersin (Turkey): Cag University.

Batista-Taran, L. C., Shuck, M. B., Gutierrez, C. C., Baralt, S. (2013). The Role of Leadership Style in Employee Engagement. South Florida Education Research Conference [interaktyvus], p. 15-20. Florida International University. Prieiga internete: http://digitalcommons.fiu.edu/cgi/viewcontent.cgi?article=1143\&context=sferc [žiūrèta 201403 10].

Dhomne, S., Hall, S. P. (2012). The impact of teambuilding and leadership styles on successful project management. The Journal of Computing Sciences in Colleges, Vol. 28, No. 2, p. 65-72. USA, North Newton: Consortium for Computing Sciences in Colleges.

Dubkēvičs, L. (2011). Lìderība vadīšanā. Rīgā: SIA „Izdevniecība RaKa“.

Fukushige, A., Spicer, D. P. (2007). Leadership preferences in japan: An exploratory study. Leadership \& Organization Development Journal, Vol. 28, Issue 6, p. 508-530. UK, Bingley: Emerald Group Publishing Limited.

Genevičiūtè-Janonienè, G., Endriulaitienè, A. (2010). Darbuotojų asmenybès bruožų, subjektyviai vertinamo transformacinio vadovavimo stiliaus, darbo motyvacijos ir ịsipareigojimo organizacijai sąveikos modelis. Psichologija, T. 41, p. 50-67. Vilnius: VU leidykla.

Goleman, D., Boyatzis, R., Mckee, A. (2007). Lyderystè. Kaip vadovauti pasitelkiant emocinị intelekta. Kaunas: Smaltija.

Gustainienè, L., Pranckevičienė, A., Briedaitytè, V. (2012). Skambučių centro darbuotojų sveikatai palankaus gyvenimo būdo ir organizacinių darbo veiksnių ryšys. Mokslas - Lietuvos ateitis, T. 4, Nr. 4. p. 311-319. Vilnius: VGTU leidykla „Technika“.

Harwati, L. N. (2013). Crisis management: Determining specific strategies and leadership style for effective outcomes. Asian journal of management sciences and education, Vol. 2, No. 2, p. 170-181. Oyama (Japan): Leena \& Luna International (Pvt) Limited.

Havenga, W., Mehana, V., Visagie, J. C. (2011). Developing a national cadre of effective leadership towards sustainable quality service delivery in South Africa. African Journal of Business Management, Vol. 5, Issue 31, p. 1227112282. Nairobi (Kenija): Academic Journals.

Ibrahim, A. S., Al-Taneiji, Sh. (2013). Principal leadership style, school performance, and principal effectiveness in Dubai schools. International Journal of Research Studies in Education, Vol. 2, No. 1, p. 41-54. Malabon City (Filipinai): Consortia Academia Publishing.

Kardelis, K. (1997). Moksliniu tyrimu metodologija ir metodai. Kaunas: Technologija.

Khan, S., Anjum, M. A. (2013). Role of leadership style and its impact on getting competitive advantage. European Journal of Applied Sciences, Vol. 5 (2), p. 53-61. Published/Hosted by International Digital Organization for Scientific Information (IDOSI).

Lussier, R. N., Achua, C. F. (2001). Leadership: Theory, Application, \& Skill Development. South-Western Cengage Learning. USA.

Monahan, B. J. (2012). School leadership mentoring characteristics in an era of significant educational reform. Filosofijos daktaro disertacija. Indiana State University. Terre Haute, Indiana, USA.

Pruskus, V. (2004). Sociologija: teorija ir praktika. Vilnius: Vilniaus teisès ir verslo kolegija.

Robbins, S. P. (2010). Kaip vadovauti žmonems. Vilnius: Tyto alba.

Rudzkienè, V. (2005). Socialiné statistika. Vilnius: MRU.

Sadeghi, A., Pihie, Z. A. L. (2012). Transformational Leadership and Its Predictive Effects on Leadership Effectiveness. International Journal of Business and Social Science, Vol. 3, No. 7, p. 186-197. USA Center for Promoting Ideas (CPI).

Sabir, M. S., Sohail, A., Khan, M. A. (2011). Impact of Leadership Style on Organization Commitment: In A Mediating Role of Employee Values. Journal of Economics and Behavioral Studies, Vol. 3, No. 2, p. 145-152. Publisher: International Foundation for Research \& Development. 
Stankevičienè, A., Lobanova, L. (2006). Personalo vadyba organizacijos sistemoje. Vilniaus Gedimino technikos universitetas. Vilnius: Technika.

Stankuvienè, A. (2013). Autoritarizmo veiksniai ir diagnostiniai instrumentai. Socialiniu mokslu studijos, Nr. 5(1), p. 57-73. Vilnius: MRU.

Stelmokienè, A., Endriulaitienè, A. (2012). Lietuviškosios modifikuoto vadovavimo efektyvumo klausimyno versijos psichometriniai rodikliai. Tarptautinis psichologijos žurnalas: biopsichosocialinis požiūris, T. 10, p. 89-108. Kaunas: VDU leidykla.

Zakarevičius, P. (2004). Vadovavimo sampratos ir turinio kaita moderniose organizacijose. Tiltai, Nr. 28, p. 1-7. Klaipèda: KU.

Адизес, И. К. (2007). Идеальный руководитель. Почему им нельзя стать и что из этого следует. Москва: Альпина бизнес букс.

Дафт, Р. Л., Лейн, П. (2007). Уроки лидерства. Москва: Эксмо.

Дмитриева, Е. Н., Тренькаева, Н. А. (2008). Возможности использования методов и приёмов коучинга в профессионально-личностном становлении студентов. Вестник Томского государственного университета. Философия. Социология. Политология, № 3(4), с. 144-147. Томск: ТГУ.

Кетс Де Врис, М. (2004). Мистика лидерства. Развитие эмоционального интеллекта. Москва: Альпина бизнес букс.

Лутохина, М. А. (2008). Педагогическая культура руководителей сферы туризма как социально-педагогическая проблема. Вестник Московского государственного областного университета, № 2, с. 60-67. Серия «Педагогика». Москва: Издательство МГОУ.

Саврук, О. Ю. (2009). Систематизація та класифікація стилів керівництва. Вісник національного університету “Львівська політехніка”, № 657, с. 74-82. Львів: Національний університет Львівська політехніка.

\title{
LEADERSHIP STYLE FINDINGS IN PROGYMNASIUMS I N KLAIP É D A
}

\author{
Ligita Šimanskiené, Arnoldas Petrulis \\ Klaipèda University (Lithuania)
}

\section{Summary}

In the analysis of leadership styles and their coherence the subject of leading the organization have been, is and will be valid at all times. Although there are quite a lot of scientific articles and books on leadership styles, but works of foreign researchers are often quoted. Unfortunately, Lithuanian scientists do not pay enough attention to new (relatively as transformational and transactional leadership styles have been begun to be analyzed in the end of last century) leadership styles, whereas a combination of leadership styles is not paid attention at all, stating a priori that it is better to use a combination of various styles. It certainly does not form serious approach to the current leadership style problem. The scientific problem is the lack of perception, identification and finding out style combinations in the field of leadership styles. The purpose of this article is finding out leadership styles set in Klaipeda progymnasiums through the analysis of leadership styles. The object of research is the leadership styles in Klaipeda progymnasiums. The research methods are analysis, synthesis and comparison based on the insights in scientific literature, which have been done in order to justify the eligibility of leadership styles chosen by the managers. Employees carried out individual questionnaires, while managers have been interviewed. To analyze, process, digest and graphically depict questionnaire data derived from quantitative research SPSS 18 (Statistical Package for the Social Sciences) software and Microsoft Office Excel 2010 program have been used.

The research confirmed the scientists ideas in the theoretical part of this article that none leadership style suits every situation. Examination of employee opinions on leadership styles of their managers showed that managers use some combination of leadership styles in their direct duties. According to the aggregated data 
from respondents' answers it may be concluded that managers consider their leadership style to be based on the combination of transformational and coaching leadership styles while also adding bits of charismatic or transactional leadership styles; employees think that managers use the combination of transformational and coaching leadership styles while also adding bits of charismatic or transactional leadership styles. Leadership style combination chosen by managers completely satisfied or more satisfied than not satisfied most of the surveyed employees in organizations. Evaluation results have showed that employees have rated leadership style of their managers better than the same managers have done. In this research the views of employees are very close to managers views when selecting the leadership style or combination of different styles.

KEY WORDS: leadership style, organization, finding, Klaipèda.

JEL CODES: M 12, M 10 